\title{
PENGELOLAAN SUMBER DAYA AIR BAWAH PERMUKAAN DENGAN TEKNOLOGI IMBUHAN BUATAN
}

\author{
Management of Subsurface Water Resources with Artificial Recharge Technology \\ Oleh: \\ Teddy W. Sudinda \\ Pusat Teknologi Lingkungan, BPPT
}

\begin{abstract}
Abstrak
Sumber air bawah permukaan merupakan sumber daya alam yang sangat penting bagi kehidupan, dan karena itu harus dilestarikan agar keberadaannya dapat digunakan secara berkelanjutan. Sumber air bawah permukaan harus dikelola secara terpadu berdasarkan cekungan air tanah yang dapat digunakan secara optimal. Untuk pelestarian air tanah menggunakan teknologi buatan mengisi ulang (recharge dangkal sumur, Deep mengisi ulang sumur dan mengisi ulang waduk). Tujuan dari penelitian ini adalah untuk menilai kemampuan penyerapan peresapan buatan di dangkal, menengah dan dalam akuifer. Kemampuan penyerapan akan diuji oleh pengukuran langsung di lapangan dengan mengisi air ke dalam sumur resapan dangkal, sumur resapan dalam dan waduk mengisi ulang di daerah tangkapan air. Semakin banyak air yang dapat diserap melalui kemampuan peresapan buatan dapat bekerja dengan baik. Dari hasil penelitian yang dilakukan dapat diketahui bahwa masing-masing memiliki keunggulan tersendiri dan dapat diimplementasikan sesuai dengan kondisi lapangan yang ada.
\end{abstract}

Kata kunci : Air Bawah Permukaan, Akuifer, Permeabilitas, Imbuhan Buatan

\begin{abstract}
Subsurface water resource is a natural resource that is essential for life, and therefore must be preserved so that its presence can be used in a sustainable manner. Subsurface water sources should be managed in an integrated manner based on ground water basin that can be used optimally. For the preservation of groundwater using artificial recharge technology (shallow recharge wells, Deep recharge wells and reservoir recharge). The purpose of this study was to assess the ability of absorption of artificial recharge in the shallow, medium and deep aquifer. Absorption capability will be tested by direct measurements in the field by filling water into shallow recharge wells, deep recharge wells and reservoirs recharge in the catchment area. The more water that can be absorbed by means of artificial recharge capabilities can work well. From the results of research conducted can be seen that each has its own advantages and can be implemented in accordance with the existing field conditions.
\end{abstract}

Keywords: Subsurface water, aquifer, Permeability, Artificial Feed

\section{PENDAHULUAN}

Saat ini permasalahan pola ketersediaan air telah menjadi semakin kompleks. Ini salah satunya merupakan dampak dari aktivitas/usaha manusia yang semakin banyak dan beragam yang turut membawa pembangunan tempat-tempat bagi kegiatan dan usaha manusia tersebut. Maka pembangunan fisik secara besar-besaran semakin tidak terhindarkan. Pengalihan fungsi lahan terus berjalan. Namun ini tidak diimbangi dengan perhatian khusus terhadap pola ketersediaan air. Fasilitas untuk drainase, pengaliran, dan peresapan tidak memadai. Biaya yang besar hanya difokuskan pada keuntungan yang lebih besar, dengan sebisa mungkin meminimalisasi cost untuk hal yang tidak terlalu penting, dan ironisnya, salah satunya adalah permasalahan air.

Kalau kita mau jujur, tidak hanya ownerowner perusahaan dan pengusaha-pengusaha kaya tersebut yang tidak peduli dan begitu semena-mena dengan kelestarian sumber daya alam ini. Tetapi kita pun rakyat biasa meski tidak berwenang secara khusus dalam pembangunan besar-besaran tersebut, kita juga turut andil dalam permasalahan ini. Ketidakpedulian kita terlihat dari pola hidup dan kebutuhan hidup kita. Jarang sekali ada rumah yang memiliki sumur resapan. Manusia benar-benar sudah jadi tuan rumah di rumah tinggalnya, sehingga akhirnya tidak peduli lagi dengan alam ini. Ketersediaan air di rumah kita terpenuhi, itu sudah cukup, tidak perlu lagi memikirkan ketersediaan air di bumi kita ini. 
Itu semua turut menyumbang ke dalam suatu permasalahan besar yang menunjukkan kondisi bumi ini sudah sangat rawan, yaitu Global Climate Change. Suatu kondisi di mana iklim bumi sudah sangat berubah, tentunya ke arah yang tidak lebih baik. Salah satu wujudnya adalah berupa pola ketersediaan air yang semakin rumit. Pada musim kemarau sangatlah kering, sementara pada musim hujan intensitasnya sangatlah besar. Maka manusia harus bersiap untuk dua kemungkinan bencana, yaitu kekeringan pada musim kemarau dan banjir pada musim hujan.

Maka, kita dapat melihat ketersediaan air saat ini permasalahannya bukan hanya terbatas pada air itu "tersedia" atau "tidak tersedia". Tetapi ada kemungkinan ketiga yaitu air tersebut sangat meluap atau berlebih sehingga manusia tidak mampu lagi mengontrolnya yang sering kita sebut dengan bencana banjir. Pengalihan fungsi lahan merupakan salah satu faktor penyebab banjir dan menurunnya permukaan air tanah di kawasan perumahan, Pengalihan lahan Hijau seperti hutan menjadi perumahan menyebabkan tidak adanya lagi area terbuka sebagai resapan air, sehingga air yang meresap ke dalam tanah menjadi kecil dan memperbesar volume aliran air permukaan. Ini semakin menjadi masalah besar beberapa tahun terakhir ini khususnya yang melanda kota Jakarta.

Salah satu cara pengelolaan air yang sangat direkomendasikan, adalah dengan Teknologi Imbuhan Buatan. Secara teoritis adalah suatu kondisi yang dibuat oleh manusia lewat mempelajari proses sirkulasi air secara alamiah. Lapisan akuifer di dalam tanah menunjukkan kemampuan meresap air yang alamiah, di mana merupakan tempat penyimpanan air secara alami. Maka Teknologi Imbuhan Buatan ini adalah usaha mengoptimalisasi peresapan air, yaitu untuk meningkatkan volume peresapan air yang terjadi, sehingga tanah kemudian menyerap sebanyak mungkin air untuk tidak terjadi luapan pada musim hujan, dan air tersebut tersedia dalam jumlah yang cukup pada waktu musim kemarau.

Maksud dan tujuan penulisan paper ini adalah untuk mengkaji teknologi imbuhan buatan yang terdiri dari sumur resapan dangkal, sumur resapan dalam dan waduk resapan. Kemampuan resapan akan diuji lewat pengukuran langsung di lapangan dengan pengisian air ke dalam sumur resapan dangkal, sumur resapan dalam dan waduk resapan. Lalu yang akan dilihat adalah debit air yang dapat diresapkan ke dalam lapisan tanah akuifer tersebut, semakin banyak air yang dapat diresapkan, berarti kapabilitas sumur tersebut semakin tinggi, sehingga menunjukkan kapasitas yang layak diterapkan.

\section{PERMEABILITAS TANAH DI WILAYAH JAKARTA DAN SEKITARNYA}

Sumberdaya air tanah Jakarta dan sekitarnya dibatasi oleh wilayah aliran air tanah, atau biasa disebut basin. Dari hulu, aliran air tanah dimulai dari lereng gunung Pangrango, gunung Gede dan gunung Salak, gunung Halimun dimana didaerah hulu ini air tanah mulai diterima oleh permukaan tanah dan kemudian meresap kedalam tanah, kemudian setelah meresap kedalam tanah, oleh akuifer dialirkannya kearah hilir sebelah selatan menjadi air tanah dangkal (air tanah bebas) dan air tanah dalam (air tanah tertekan, atau sering disebut juga air tanah artesis). Selanjutnya sesampainya dikawasan utara, yang diatasnya meliputi wilayah Kabupaten Bogor, kota Depok, sebagian Kabupaten dan kota Tangerang, sebagian wilayah kabupaten dan kota Bekasi dan paling besar adalah Propinsi DKI Jakarta, lapisan tanah pembawa air tanah (akuifer) terbagi lagi menjadi beberapa lapisan yang semakin kompleks dan sifatnya sangat lokal .

Akuifer Jakarta secara geologis memperlihatkan strata tanah yang sangat beragam dan sangat kompleks. Namun sulit untuk membaginya secara tegas lapis demi lapis pada akuifer Jakarta. Karena di setiap tempat terdapat zona - zona air tanah yang terperangkap. Untuk memudahkan, akuifer Jakarta dapat dikelompokkan menjadi 3 (tiga) lapis, yaitu akuifer air tanah dangkal (akuifer bebas) yang mempunyai kedalaman hingga 50 meter dibawah muka tanah, lalu akuifer tertekan (akuifer artesis) mempunyai kedalaman antara 50 hingga 150 meter dibawah muka tanah dan yang terakhir akuifer tertekan (akuifer artesis), mempunyai kedalaman antara 150 hingga 250 meter dibawah permukaan tanah.

Akuifer artesis biasanya disebut akuifer dalam. Dilihat dari segi jenis tanahnya, akuifer Jakarta pada umumnya merupakan butiran pasir lepas, tanah aluivial walaupun diselang seling dengan tanah lempung yang kedap air (yang ini kelak membuat akuifer itu tidak menerus) mempunyai potensi yang sangat baik sebagai penyimpan air tanah. Jika dilihat secara lokal, dengan tingkat kelulusan yang tinggi, maka dapat diperkirakan bahwa porositas dan konduktivitas hidrolis mempunyai besaran yang tinggi, namun kecepatan aliran air tanah secara menyeluruh (total) rendah, diakibatkan sangat jarang ada akuifer yang menerus. Dampak dari rendahnya kecepatan aliran air tanah ini dapat menyebabkan defisit neraca air pada wilayah atau kawasan tertentu. Berikut adalah peta lapisan akuifer di Jakarta menurut dua penampang, utara-selatan, barat-timur (Gambar 1 dan Gambar 2). 


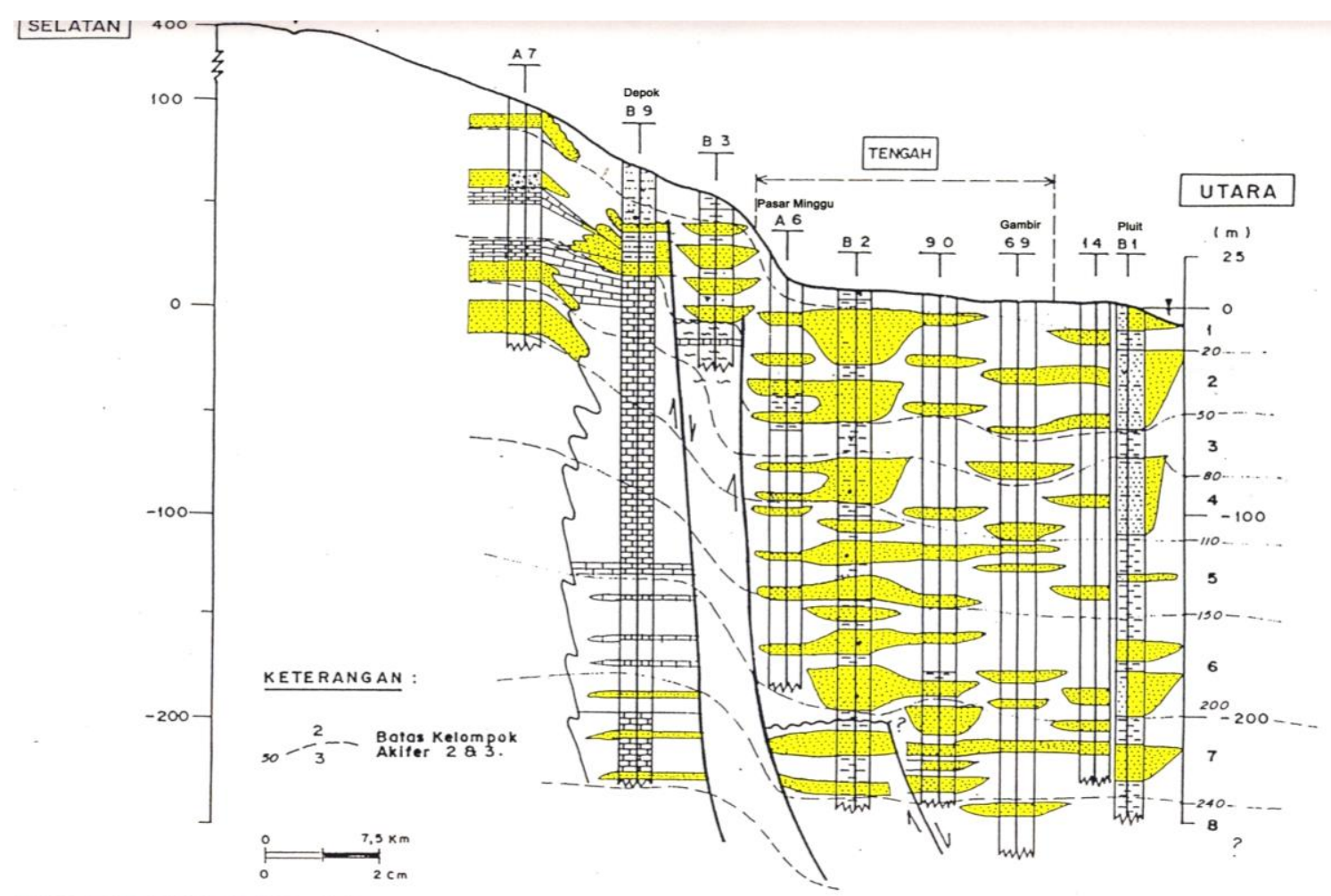

Gambar 1. Penampang Selatan-Utara ("Gambaran Kondisi Akifer Air tanah DKI Jakarta Untuk sumur resapan dalam" - A. Asseggaf 2009).

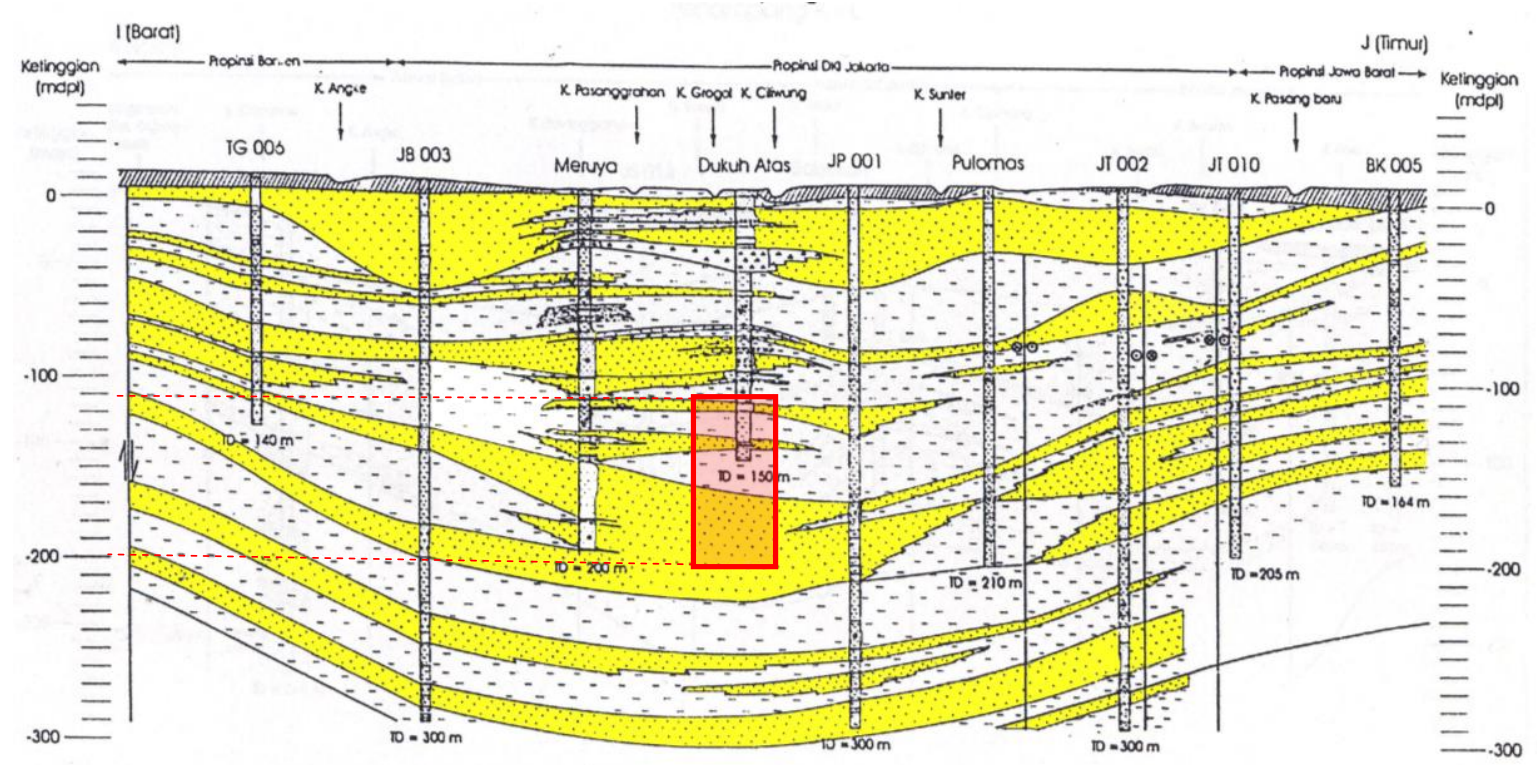

Skalo horizontal :

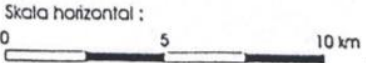

Gambar 2. Penampang Barat-Timur ("Gambaran Kondisi Akifer Air Tanah DKI Jakarta Untuk Sumur Resapan Dalam" - A. Asseggaf 2009) 


\subsection{Manfaat Teknologi Imbuhan Buatan}

Secara spesifik tujuan dari suatu imbuhan buatan, seperti diuraikan oleh W.C. Walton dalam bukunya "Groundwater Resource Evaluation" adalah sebagai berikut :

- Konservasi dan mengatur runoff dan limpasan air.

- Menyuplai kuantitas air tanah.

- Menahan atau mengurangi penurunan water level di reservoir air tanah.

- Mengurangi atau menjaga keseimbangan intrusi air laut.

- Menyimpan air untuk mengurangi biaya pemompaan dan penyaluran.

- Menyimpan air pada musim kemarau untuk digunakan pada musim hujan.

- Konservasi energi dalam aplikasi geothermal

- Mengurangi zat padat yang mengendap dengan filtrasi melalui tanah.

Suatu lapisan akuifer paling baik jika dapat menyerap air dalam kuantitas yang yang besar dan tidak terlalu cepat melepaskan air tersebut. Secara teoritis ini akan mengakibatkan konduktivitas hidrolik vertikal tinggi, sementara konduktivitas hidrolik horizontal sedang. Secara alamiah, jarang ada lapisan dengan dua kondisi seperti ini sekaligus. Maka ini mendasari direkomendasikannya resapan buatan.

\subsection{Sumur Resapan Dangkal}

Sumur resapan dangkal merupakan satu dari sekian banyak alternatif dalam mengatasi banjir dan menurunnya permukaan air tanah. Manfaat dari pembuatan sumur resapan dangkal antara lain adalah, mengurangi aliran permukaan dan mencegah terjadinya genangan air sehingga mengurangi kemungkinan banjir dan erosi, mempertahankan tinggi muka air tanah dan menambah persediaan air tanah, mengurangi intrusi air laut, mencegah penurunan tanah akibat pengambilan air berlebih. Namun pembuatan sumur resapan dangkal tetap memiliki kekurangan. Pertama, tidak mudah untuk memasyarakatkan setiap rumah wajib memiliki sumur resapan, karena jika dalam suatu kawasan hanya ada satu atau dua rumah saja yang memiliki sumur resapan, pengaruhnya tidak akan terlalu signifikan. Kedua, kalaupun sumur resapan telah banyak dibuat, diperkirakan ini tetap tidak akan mampu menampung limpasan air hujan yang terus meningkat. Kondisi tersebut disebabkan porositas atau daya serap tanah yang kurang memadai.

Pemanenan Air Hujan (PAH) kontruksinya terbuat dari beton (Gambar 3), bentuk kotak, panjang $500 \mathrm{~cm}$, dalam $235 \mathrm{~cm}$ dan lebar $110 \mathrm{~cm}$ dilengkapi dengan pompa dan filter untuk pemanfaatan air yang telah ditampung. Air yang sudah tertampung kedalam tangki PAH dapat dimanfaatkan sebagai air bersih yang dapat digunakan untuk keperluan mandi, cuci, kakus (MCK). Untuk itu dilengkapi dengan pompa sedot, filter dan control panel. Kontrol panel berfungsi untuk mengatur jalannya pompa, memberikan tanda kepada operator apakah dalam tangki PAH ada air atau kosong. Indikasi adanya air dalam tangki PAH ditandai dengan lampu yang menyala hijau.

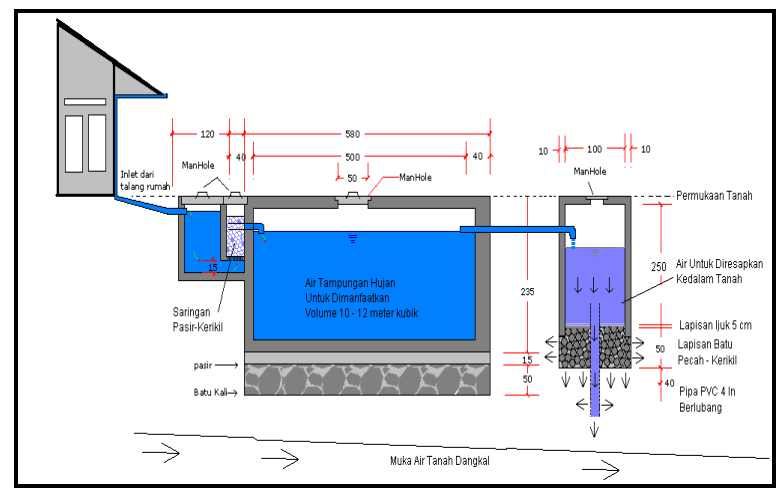

Gambar 3. Sistem Pemanenan Air Hujan (PAH) Dan Sumur Resapan. (Arie dkk, 2010)

Pengujian sumur dilakukan dengan tujuan untuk mengetahui kemampuan sumur resapan memasukan air dalam satuan waktu tertentu dan mengetahui kemampuan tanah dalam meresapkan air. Pengujian dilakukan dengan dua cara, yaitu cara langsung dan tidak langsung. Pengujian langsung dengan cara memasukkan air (dari PDAM) dengan mobil tangki ke dalam sumur resapan. Ketinggian posisi awal air diukur, kemudian secara berkala dengan selang waktu 5 menit diukur besarnya penurunan air di dalam sumur resapan. Pengukuran dilakukan sampai air di dalam sumur resapan habis.

Hasil pengujian dengan pengisian langsung adalah sebagai berikut: pada tahap awal pengamatan terlihat bahwa peresapan air sangat pesat masuk kedalam akuifer air tanah dangkal, air mampu meresap dengan penurunan $11 \mathrm{~cm} /$ menit, namun secara perlahan-lahan kecepatan peresapan menurun sejalan dengan waktu, hingga mencapai 35 $\mathrm{cm} / 5$ menit, hingga akhirnya mendekati konstan pada kecepatan 0,025 cm/menit (Gambar 4 dan Gambar 5).

Hasil Penelitian PAH dan Sumur Resapan:

1) Pemanenan Air Hujan (PAH) yang dibangun dengan kapasitas $10 \mathrm{m3}$, dapat dimanfaatkan untuk keperluan sehari-hari, seperti cuci tangan, mengisi bak kamar mandi dan menyiram tanaman, sehingga pemakaian air berlangganan dari PDAM bisa dihemat. 
2) Jika sumur resapan telah penuh, maka limpasannya (overflow) dialirkan kedalam sumur resapan.

3) Hasil pengujian resapan yang dilakukan untuk karakterisasi sumur resapan di SD 1,2,3 dan 4, Kawung Luwuk, Desa Bantarjati, Bogor Utara kecepatan permeabilitas tanah rata-rata setempat 1,3-3,6 $\mathrm{mm} /$ menit.

4) Depok kecepatan permeabilitas tanah rata-rata setempat 2,4-2,7 mm/menit.

5) Hasil pengujian resapan yang dilakukan untuk karakterisasi sumur resapan di SMA Al' Azhar, Jakarta Selatankecepatan permeabilitas tanah rata-rata setempat $2,9 \mathrm{~mm} /$ menit.

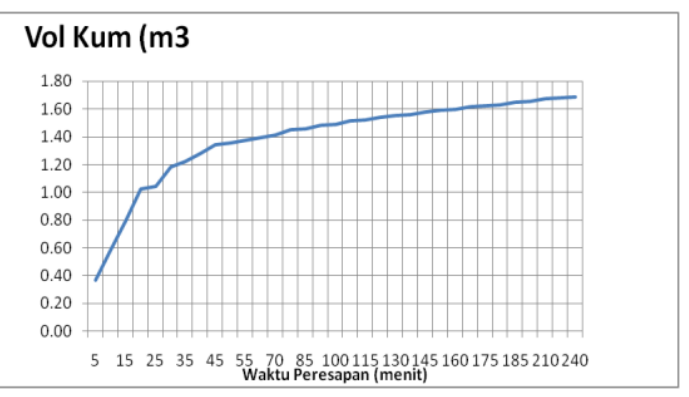

Gambar 4. Banyaknya Volume Air $\left(\mathrm{m}^{3}\right)$ Yang Masuk Ke dalam Sumur Resapan Dalam Setiap Penambahan Waktu (menit). (Arie dkk, 2010).

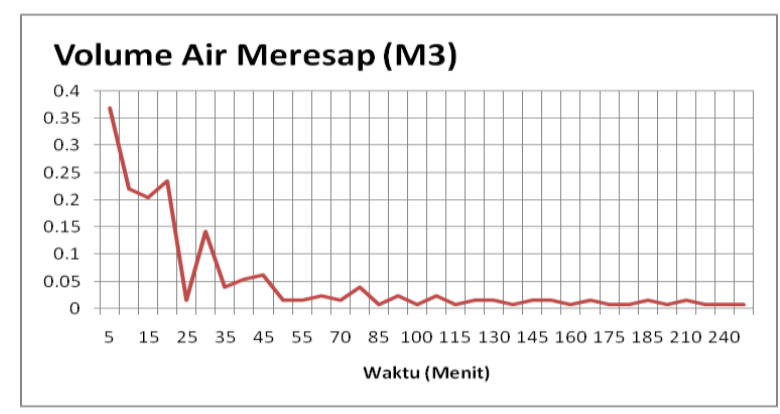

Gambar 5. Banyaknya Volume Air $\left(\mathrm{m}^{3}\right)$ Yang Masuk Ke dalam Sumur Resapan Dalam Setiap Penambahan Waktu (Menit). (Arie dkk, 2010).

\subsection{Sumur Resapan Dalam}

Gedung-gedung bertingkat semakin banyak, yang biasanya persediaan airnya mengambil dari lapisan akuifer yang jauh berada di dalam tanah. Maka kuantitas air di lapisan akuifer dengan cepat akan terus berkurang dan berakibat penurunan tanah akan semakin menjadi. Ini tentunya tidak bisa diatasi dengan sumur resapan yang hanya berpengaruh pada lapisan dangkal. Maka diperlukan peningkatan pemberdayaan sumur resapan, dan salah satu alternatifnya adalah dengan sumur resapan dalam dengan menginjeksikan air hingga ke lapisan akuifer dalam. Tercetusnya hal ini salah satunya karena melihat semakin banyaknya high raise building di Jakarta yang berakibat semakin tereksploitasinya persediaan air tanah lewat pengambilan air dari lapisan akuifer dalam yang berada di lapisan tanah tertekan yang jauh berada di dalam tanah untuk mencukupi persediaan air secara massal di bangunan-bangunan tersebut. Maka ide dasar dari pembuatan sumur injeksi dalam adalah mengembalikan/restoring air ke dalam lapisan akuifer dalam untuk menjaga keseimbangan persediaan air di dalam tanah yang akan sangat banyak manfaatnya yaitu untuk konservasi air, mencegah banjir, mencegah menurunnya permukaan tanah.

\subsubsection{Pemboran Sumur Resapan Dalam}

Sebagai acuan dalam perencanaan pemboran akuifer dalam adalah data pemboran yang paling dekat dengan Gedung BPPT (Tabel 1), yaitu di Parkir Gedung Jaya. Kisaran kedalam saringan akuifer berada pada kedalaman 177-193 meter dengan penurunan muka air tanah sampai 2,27 meter selama 3 tahun (Januari 2001 sampai Januari 2004).

Tabel 1. Data Perubahan Muka Air tanah Pada Akuifer IV (140 - 190 m)

\begin{tabular}{|c|c|c|c|c|c|}
\hline \multirow[b]{2}{*}{ NO } & \multirow{2}{*}{$\begin{array}{c}\text { LOKASI } \\
\text { (No Lokasi \& } \\
\text { Daerah) }\end{array}$} & \multirow{2}{*}{$\begin{array}{l}\text { KISARAN } \\
\text { KEDALAMAN } \\
\text { SARINGAN } \\
\text { (Meter) }\end{array}$} & \multicolumn{2}{|c|}{$\begin{array}{c}\text { KONDISI M.A.T. IV } \\
(\mathrm{m}, \mathrm{mts})\end{array}$} & \multirow[b]{2}{*}{$\begin{array}{c}\text { SELISIH MAT } \\
\text { (Meter) }\end{array}$} \\
\hline & & & $\begin{array}{l}\text { JANUARI } \\
2001\end{array}$ & $\begin{array}{l}\text { JANUARI } \\
2004\end{array}$ & \\
\hline 1 & 10, DPR/MPR & $147-185$ & -10.81 & -25.00 & $-14.19(\mathrm{~T})$ \\
\hline 2 & $\begin{array}{l}\text { 17, Kamal } \\
\text { Muara }\end{array}$ & $153-188$ & -24.16 & -24.60 & $-0.42(T)$ \\
\hline 3 & 32B, Sunter-III & $173-177$ & -21.57 & -21.86 & $-0.29(\mathrm{~T})$ \\
\hline 4 & $\begin{array}{l}\text { 22, Parkir } \\
\text { Gedung Jaya }\end{array}$ & $177-193$ & -18.75 & -21.02 & $-2.27(\mathrm{~T})$ \\
\hline 5 & $\begin{array}{l}\text { 33, Tambun } \\
\text { Rengas }\end{array}$ & $187-190$ & -15.32 & -15.29 & $+0.03(\mathrm{~N})$ \\
\hline
\end{tabular}

Untuk melakukan pemboran sebelumnya dilakukan kompilasi data dari pemboran sumur yang ada di sekitar Gedung BPPT, yaitu Petamburan, Jatibaru, Menteng, Gondangdia dan Cikini. Data tersebut bisa memperkirakan secara garis besar mengenai akuifer yang ada di Gedung BPPT.

Pada bulan Agustus di area Gedung BPPT telah dilakukan pembuatan sumur resapan dalam untuk konservasi airtanah. Kedalaman sumur 193 meter dengan penempatan screen pada akuifer dilakukan pada kedalaman 139-162 meter dan 167-184 meter (Gambar 6 dan Gambar 7). 


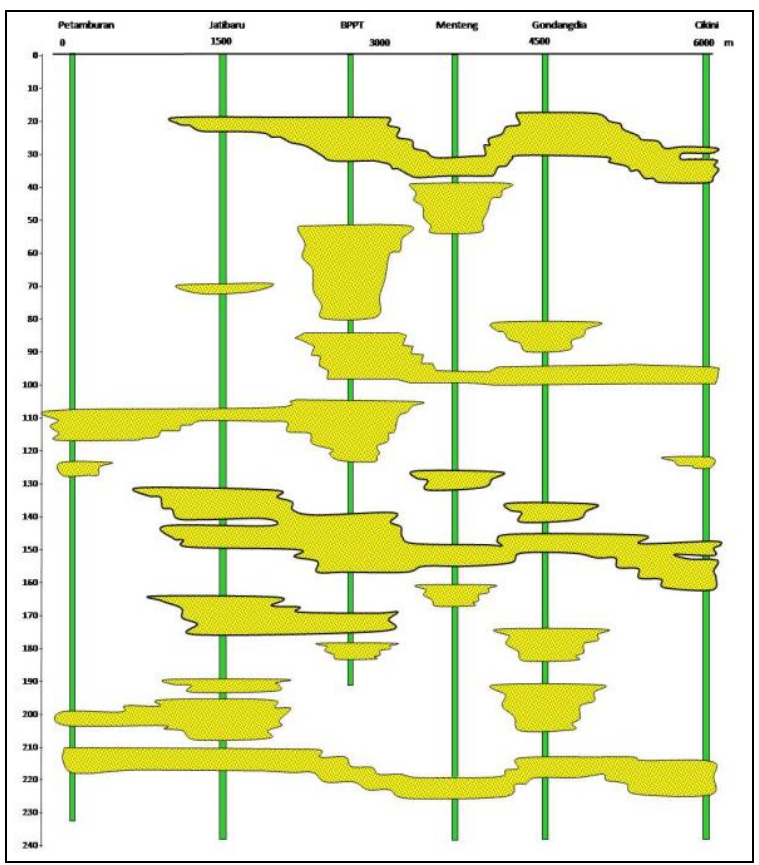

Gambar 6. Pemboran Akuifer Dalam Di Gedung BPPT Dan Korelasi Dengan Sumur-Sumur Di Sekitarnya.

Lapisan akifer dalam tidak tercampur dengan lapisan akifer dangkal, tinggi muka airtanah (tma) dalam 20.45 meter, diameter pipa di bawah 6 inch, sedangkan diameter pipa di atas 8 inch. Disamping sumur injeksi dalam tersebut dibangun juga sumur pantau dengan kedalaman 30 meter dengan tinggi muka air tanah (tma) 3 meter.

\subsubsection{Analisis Pengukuran Sumur Resapan Dalam}

Pengujian sumur dilakukan untuk menghitung kapasitas resapan (infiltrasi) air yang masuk ke dalam sumur. Prinsip kerjanya adalah; pertama kali dengan mengukur tinggi muka air tanah awal (tma) dari permukaan tanah, kemudian memasukkan air ke dalam sumur dari tangki air dengan debit tetap hingga penuh, dan diukur kenaikan muka air tanah per satuan waktu. Setelah sumur penuh sampai di permukaan tanah, kemudian diukur tingkat penurunannya hingga keadaan muka air sumur seperti semula.

Pengukuran tingkat serapan (infiltrasi) sumur di BPPT dilakukan 2 kali. Tinggi muka air tanah awal (tma) 20.45 meter, lama pengisian 16 menit dengan debit injeksi sebesar 85,71 liter/menit, dan terjadi kenaikan muka airtanah sebesar 20.45 meter hingga permukaan. Kemudian dilakukan pengukuran penurunan muka air tanah selama 40 menit hingga tinggi muka air tanah (tma) seperti semula sebelum dilakukan pengisian air.

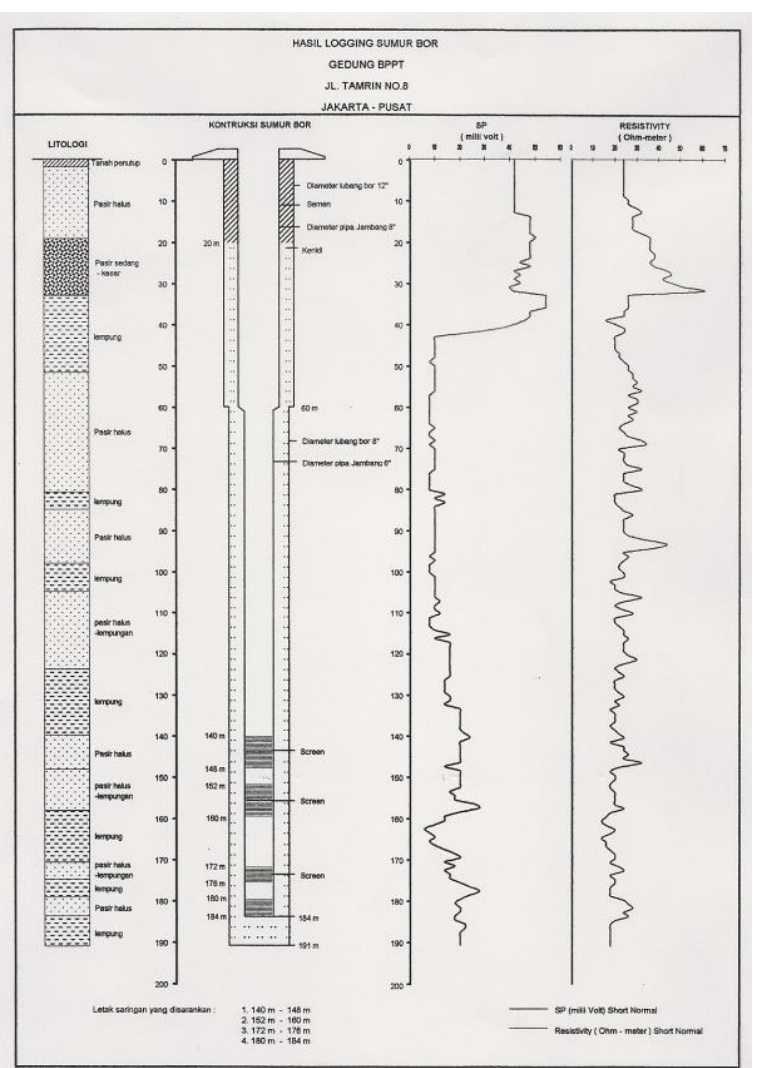

Gambar 7. Profil Perlapisan Tanah Sumur Resapan Dalam BPPT.

Percobaan Pertama :

Hasil percobaan pertama uji coba sumur di BPPT dapat dilihat pada Tabel 2 dan Gambar 8.

Tabel 2. Deskripsi Uji Coba Sumur Di BPPT (Percobaan 1).

\begin{tabular}{|c|c|}
\hline Deskripsi Sumur & Keterangan \\
\hline \multicolumn{2}{|l|}{ Kenaikan Muka Airtanah } \\
\hline $\begin{array}{l}\text { Tinggi Muka Airtanah awal } \\
\text { (Tma Awal) }\end{array}$ & $20.45 \mathrm{~m}$ \\
\hline $\begin{array}{l}\text { Tinggi Muka Airtanah Akhir } \\
\text { (Tma akhir) }\end{array}$ & $0 \mathrm{~m}$ \\
\hline Tebal air sumur $(\Delta d)$ & $172.55 \mathrm{~m}$ \\
\hline Lama Pengisian $(\Delta \mathrm{t})$ & 16 menit \\
\hline Debit Injeksi & 85.71 liter/menit \\
\hline Total air yang masuk & 1371.36 liter \\
\hline \multicolumn{2}{|l|}{ Penurunan Muka Airtanah } \\
\hline $\begin{array}{l}\text { Tinggi Muka Airtanah Awal } \\
\text { (Tma Awal) }\end{array}$ & $0.0 \mathrm{~m}$ \\
\hline $\begin{array}{l}\text { Tinggi Muka Airtanah Akhir } \\
\text { (Tma Akhir) }\end{array}$ & $21.45 \mathrm{~m}$ \\
\hline Tebal air sumur $(\Delta d)$ & $21.45 \mathrm{~m}$ \\
\hline Lama Penurunan $(\Delta t)$ & 40 menit \\
\hline \multicolumn{2}{|l|}{ Kapasitas Infiltrasi Sumur } \\
\hline Sumur dalam BPPT & $2.057 \mathrm{~m}^{3} / \mathrm{jam}$ \\
\hline
\end{tabular}


Dari Gambar 8 dapat dilihat bahwa grafik penurunan muka air tanah ada kecenderungan tingkat penurunan muka air tanahnya memiliki pola yang tetap, sehingga untuk mendekati tinggi muka air tanah seperti semula diperlukan waktu hanya 40 menit.

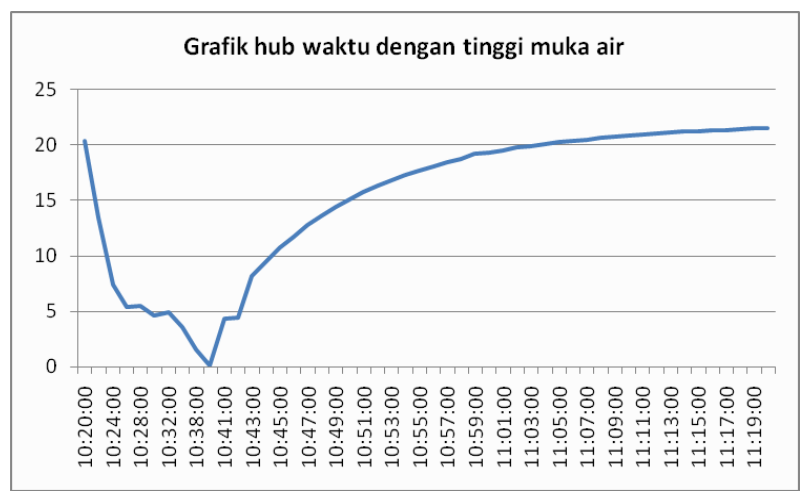

Gambar 8. Grafik Kenaikan Dan Penurunan Muka Air Tanah Di BPPT.

Percobaan Kedua :

Hasil percobaan kedua uji coba sumur di BPPT dapat dilihat pada Tabel 3 dan Gambar 9.

Tabel 3. Deskripsi uji coba sumur di BPPT (Percobaan 2).

\begin{tabular}{|c|c|}
\hline Deskripsi Sumur & Keterangan \\
\hline \multicolumn{2}{|l|}{ Kenaikan Muka Airtanah } \\
\hline $\begin{array}{l}\text { Tinggi Muka Air Tanah awal } \\
\text { (Tma Awal) }\end{array}$ & $21.45 \mathrm{~m}$ \\
\hline $\begin{array}{l}\text { Tinggi Muka Air Tanah Akhir } \\
\text { (Tma akhir) }\end{array}$ & $0 \mathrm{~m}$ \\
\hline Tebal air sumur $(\Delta \mathrm{d})$ & $171.55 \mathrm{~m}$ \\
\hline Lama Pengisian $(\Delta \mathrm{t})$ & 10 menit \\
\hline Debit Injeksi & 82.19 liter/menit \\
\hline Total air yang masuk & 821.91 liter \\
\hline \multicolumn{2}{|l|}{ Penurunan Muka Airtanah } \\
\hline $\begin{array}{l}\text { Tinggi Muka Airtanah Awal } \\
\text { (Tma Awal) }\end{array}$ & $0.0 \mathrm{~m}$ \\
\hline $\begin{array}{l}\text { Tinggi Muka Airtanah Akhir } \\
\text { (Tma Akhir) }\end{array}$ & $20.53 \mathrm{~m}$ \\
\hline Tebal air sumur $(\Delta d)$ & $20.53 \mathrm{~m}$ \\
\hline Lama Penurunan $(\Delta t)$ & 40 menit \\
\hline \multicolumn{2}{|l|}{ Kapasitas Infiltrasi Sumur } \\
\hline Sumur dalam BPPT & $1.232 \mathrm{~m}^{3} / \mathrm{jam}$ \\
\hline
\end{tabular}

Dari perhitungan di atas maka dapat diketahui kapasitas infiltrasi untuk sumur dalam di BPPT berkisar diantara $1.23-2.1 \mathrm{~m}^{3} / \mathrm{jam}$. Tingkat resapan sumur ini relatif besar, kalau debit yang masuk relative tetap, maka kapasitas sumur akan mampu menyerap semua air yang ada, tetapi apabila terdapat debit yang relatif besar dalam waktu yang singkat seperti dari talang air dengan intensitas hujan tinggi, maka sumur akan meluap. Saluran pipa sebagai overland flow (air luapan) rencana juga disiapkan untuk mengantisipasi apabila terjadi luapan air dari air hujan. Gambar 9 memperlihatkan grafik kenaikan dan penurunan muka airtanah pada sumur resapan dalam di BPPT pada percobaan ke 2 .

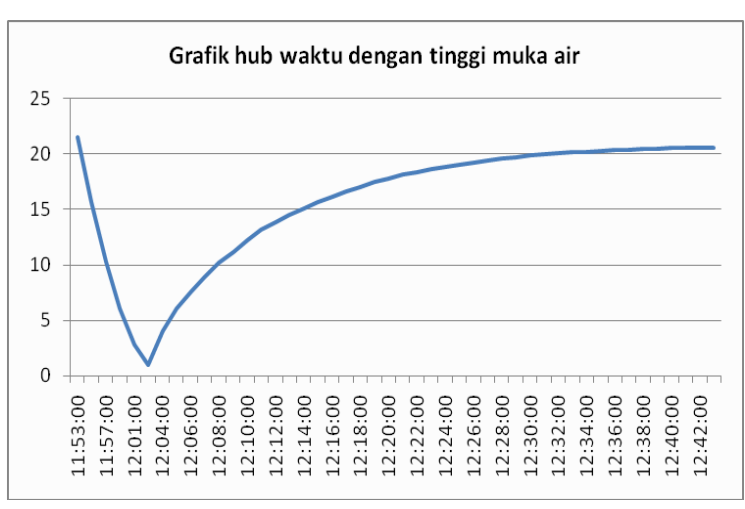

Gambar 9. Grafik Kenaikan Dan Penurunan Muka Air Tanah Di BPPT

Dari Gambar 9 tersebut dapat dilihat bahwa grafik penurunan muka air tanah ada kecenderungan tingkat penurunan muka air tanahnya memiliki pola yang tetap dan cenderung semakin lama semakin mendatar, sehingga untuk mendekati tinggi muka airtanah seperti semula diperlukan waktu sekitar 42 menit.

\subsubsection{Hasil Kajian Sumur Resapan Dalam}

Hasil kajian resapan Teknologi Resapan Dalam (Sumur Injeksi) :

a. Lokasi sumur resapan dalam yang berada di area BPPT mempunyai kedalman 190 meter dan MATnya dalah 21 meter mempunyai kapasitas hingga $2,5 \mathrm{~m} 3 /$ jam.

b. Hasil uji sumur imbuhan dalam di BPPT membuktikan bahwa sumur resapan dalam mempunyai potensi yang cukup baik untuk meresapkan air secara kontinyu, dan kapasitas hampir mencapai $2,5 \mathrm{~m} 3 / \mathrm{jam}$ atau setara dengan $20.000 \mathrm{~m} 3 /$ tahun.

c. Berdasarkan kapasitas tersebut, maka sumur resapan dalam mampu memberikan dampak yang positif terhadap keberadaan aritanah dalam.

\subsection{Waduk Resapan}

Waduk Resapan (WR) merupakan pengembangan dari sumur resapan (SR) satu pihak dan bendung/waduk di pihak lain. SR merupakan resapan pasif, walaupun dasar sumur cukup lolos air (permeable) karena digali sampai lapisan porous, 
akan tetapi suplai air hanya dari hujan yang tidak selalu ada (pasif). WR dibuat dengan menggali lahan sampai kedalaman lapisan aquifer. Volume galian menjadi volume tampungan air seperti waduk. Sumber air ke WR selain limpasan air hujan dari lahan sekitarnya (Catchment area) dan juga suplesi dari sungai dengan mengelakan aliran sungai ke WR dengan bendung. Jadi letak WR sebaiknya dekat alur sungai, sehingga selalu ada air (baik saat banjir/normal) dan tidak diperlukan saluran pembawa/suplesi yang panjang. Jadi WR merupakan metoda resapan aktif.

Teknologi bendung diperlukan di WR untuk pengambilan/pengelakkan air, jadi ada mercu/pelimpah untuk menaikkan muka air sungai sehingga bisa masuk ke intake saluran pembawa WR, Saluran pembawa juga berfungsi sebagai kantong lumpur untuk menjernihkan air dari sungai. Intake merupakan ambang lebar yang dapat mengukur debit dan dilengkapi pintu sorong untuk buka tutup debit dalam operasi dan pemeliharaan (O-P WR). Didepan intake dilengkapi pintu bilas untuk membuang sedimen dan sampah yang berada didepan intake, agar tetap bersih dan tidak mengganggu debit intake. WR dilengkapi dengan pintu pembuangan berupa ambang lebar dan pintu sorong, untuk mengukur debit lebih yang tidak meresap ke lapisan tanah /aquifer bawah WR. Jadi untuk mengetahui sesaat air resapan cukup mengukur debit intake (inflow) dan debit buang (outflow) dan menyelisihkan pada periode tertentu dimana aliran/ resapan sudah cukup stabil (steady flow).

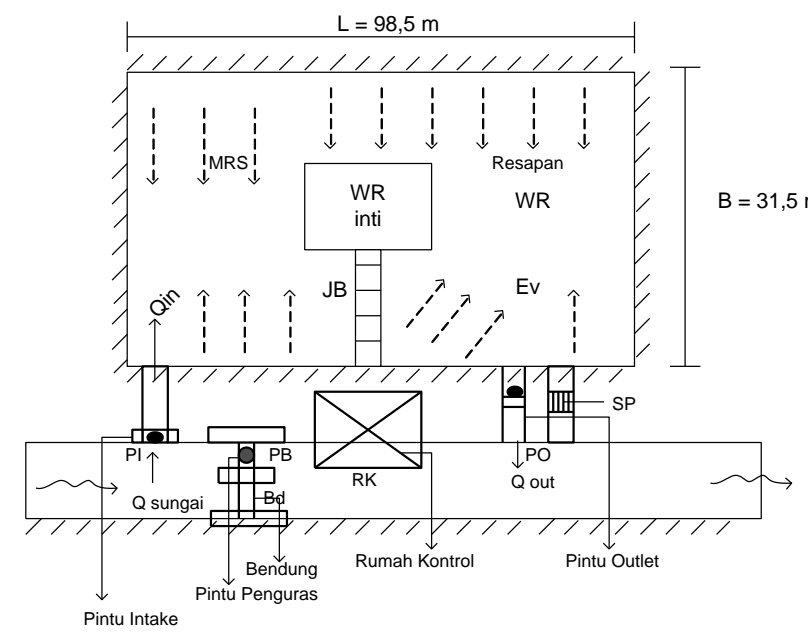

Gambar 10. Skematis Komponen Bangunan Air Waduk Resapan.

Kinerja WR dapat ditingkatkan dengan membuat sumur dibagian tengah WR, dengan dasar lebih dalam yang mencapai lapisan aquifer dibawahnya yang lebih permable, sehingga intensitas resapan lebih deras/tinggi yang mempunyai jangkauan resapan yang lebih luas/jauh. WR sebaiknya dilengkapi peralatan monitoring seperti sumur pantau (piezometer) tekanan air pori dan pemeriksaan kualitas air. Data tekanan air pori di sumur-sumur pantau dapat dikonek secara integral ke ruang baca yang aman (Kantor Pusat Data). Data tersebut sangat penting untuk evaluasi debit resapan. Secara skematis komponen-komponen bangunan air waduk resapan secara umum diberikan pada Gambar 10.

\subsubsection{Penerapan Teknologi Waduk Resapan}

Dalam penerapan teknologi WR diperlukan persiapan antara lain pintu penguras, bendung, intake dan outlet diperiksa dengan membuka menutup. Semua pintu berupa pintu sorong sehingga untuk membuka ditarik ke atas dan menutup diturunkan. Operasi pintu sorong dijalankan dengan memutar pegangan putar (handle). Pemeriksaan meliputi kebocoran dan adanya sampah serta endapan di dasar ambang. Semua sampah dan sedimen yang mengganggu dibersihkan. Dimensi pintu yaitu lebar dan tinggi ambang diukur beberapa kali: 3 kali kiri, tengah dan kanan. Pintu sorong dibiarkan dalam keadaan terbuka beberapa waktu untuk memastikan tidak ada sampah lagi dan sedimen di atas ambang.

Pintu penguras bendung ditutup untuk menaikkan air di sungai sehingga diperoleh muka air sungai diatas ambang intake. Pintu intake dibiarkan terbuka dan secara perlahan air sungai masuk ke ambang intake dan masuk ke waduk. Setelah muka air disungai tetap sesuai dengan penutupan pintu penguras, air masuk ke waduk lewat ambang intake yang mempunyai elevasi tetap; pada kondisi ini diperoleh debit masuk (inflow) ke WR sudah tetap.

Debit air mulai mengisi waduk dan muka air waduk mulai naik perlahan-lahan. Pintu air outlet dibiarkan dalam keadaan terbuka penuh sehingga muka air waduk jika sudah melebihi ambang outlet air secara sedikit demi sedikit keluar (outflow) dan ditunggu sampai elevasi atau tebal muka air diatas ambang outlet tetap, dimana diperoleh kondisi aliran inflow dan outflow diwaduk sudah seimbang atau didapat kondisi aliran tetap (steady flow).

Pengukuran debit dimulai setelah didapat kondisi aliran tetap atau muka air diatas intake, didalam waduk dan diatas ambang outlet tetap. Pengukuran dilakukan dengan mengukur lebar basah dan kedalaman air diatas ambang untuk mendapatkan luas basah. Pengukuran dilakukan 3 kali setiap titik dan minimal diambil 3 titik (kanan, tengah dan kiri) dan lebar dilakukan dihulu, tengah dan hilir.

Kecepatan air diukur dengan 2 metode, yaitu dengan pelampung bergerak (floating object) dan 
dengan current meter. Pengukuran kecepatan dengan metoda floating object mencatat jarak jelajah dan waktu tempuh benda apung. Sedangkan pencatatan kecepatan dengan current meter adalah mencatat jumlah putaran selama selang waktu tertentu. Untuk mendapatkan nilai kecepatan diperlukan koefisien kalibrasi nilai putaran per detik, yang disediakan sesuai type dan merek current meter.

\subsubsection{Hasil Kajian Waduk Resapan}

Hasil Kajian kemampuan resapan Teknologi Waduk Resapan :

Hasil uji kerja waduk resapan di UI Depok dapat disimpulkan nilai laju resapan cukup besar dalam satuan standarisasi 1 ha, yaitu 4295,8 $\mathrm{m}^{3} /$ ha/hari atau 143 - 149 kali lebih besar dibandingkan nilai infiltrasi lahan terbuka pada umumnya atau WR sangat efektif.

\section{KESIMPULAN}

Dari penbahasan diatas telah dikaji kemampuan resapan Teknologi Imbuhan Buatan yang terdiri dari Teknologi Sumur Resapan, Teknologi Sumur Injeksi dan Teknologi Waduk Resapan. Dimana wilayah yang dijadikan sebagai pilot projek adalah wilayah yang mempunyai lapisan akifer dengan permeabilitas yang cukup porous sehingga air dengan mudah dapat meresap pada akifer tersebut. Untuk sumur resapan dangkal dilengkapi dengan pemanen air hujan (PAH) yang berfungsi sebagai bak penampung dan apabila air melimpas akan di resapkan ke sumur resapan. Lokasi kajian di sekolahsekolah yang merupakan tempat yang sangat strategis yang dapat mensosialisasikan teknologi tersebut ke siswa dan diharapkan seluruh sekolah di wilayah jakarta dapat mengimplematansikan Teknologi ini.

Sedangkan untuk teknologi sumur resapan dalam (sumur injeksi) merupakan upaya yang dilakukan untuk menggantikan air yang diambil dari akifer dalam terutama untuk gedung-gedung tinggi di kota Jakarta. Dalam hal ini yang perlu diperhatikan adalah dalam menentukan screen harus tepat pada akifer yang telah terjadi penurunan muka air tanah dan mempunyai permeabilitas yang cukup tinggi, sehingga air dengan mudah dapat meresap dengan mengandalkan perbedaan tinggi tekan. (hidraulic head). Air yang di injeksikan tidak mengandung sedimen yang dapat mengakibatkan sumbatan pada screen.

Teknologi Waduk Resapan merupakan teknologi imbuhan buatan yang memotong lapisan tanah sampai dengan lapisan akifer. Sehingga air dengan mudah meresap kedalam akifer dengan mengandalkan perbedaan tinggi tekan dari tinggi muka air di waduk dan tinggi muka air tanah. Persyaratan dalam teknologi ini diperlukan pintu air yang mengisi air ke waduk yang berasal dari sungai yang dibendung dengan elevasi sehingga mempunyai tinggi tekan yang signifikan.

\section{DAFTAR PUSTAKA}

- $\quad$ Arsyad, S. 2006. Konservasi Tanah dan Air.IPB Press. Bogor

- $\quad$ Arie dkk, 2010, Pemanen Air Hujan dan Sumur Resapan,jakarta

- Chow, Van Te. 1960. Handbook of Applied Hydrology. McGraw-Hill Book Co., Inc. N.Y.

- Kalsim, D.K. 2007. Catatan Kuliah Hidrologi Teknik Lanjutan. Jurusan Sipil dan Lingkungan. IPB.Bogor.

- $\quad$ Kirpich, P.Z.1940. Time of Concentration of Small Agricultural watershed. Civil Eng.:10:362.

- Kurniatun Hairiah et al.,2004. Ketebalan seresah sebagai indikator Daerah Aliran Sungai (DAS) sehat. World Agroforestry Centre, Bogor.

- Wisler, C.O., and E.F. Brater. 1959. Hydrology. John Wiley \$Sons, Inc.,N.Y.

- Deny, J. 1994. Kelestarian Imbuhan Air Tanah Dengan Memanfaatkan Teknologi Konservasi Air Tanah. Dalam Seminar Memasyarakatkan Penggunaan Air tanah di Wilayah Jakarta Seefisien Mungkin. Jakarta, 26 Oktober 1994.

- Dinas Pertambangan Daerah Tingkat I Jawa Tengah dengan Direktorat Geologi Tata Lingkungan. 1995. Pengamatan Resapan Air bawah Tanah daerah Semarang dan Sekitarnya. Semarang. Proyek Pengawasan dan Pengendalian Pengambilan Air Bawah Tanah di Kodya Semarang, Surakarta Kabupaten semarang, Kendal dan Sukohardjo.

- Pemerintah Daerah Khusus Ibukota Jakarta, Brosur, Sumur Resapan Buatan Air Hujan. Jakarta. Dinas Pertambangan DKI.

- Sunjoto. 1992. Brosur Sistem Drainase Air Hujan Berwawasan Lingkungan. Yogyakarta. Fakultas Teknik Universitas Gadjah Mada.

- Asseggaf, A., 1998. Hidrodinamika Airtanah Alamiah Cekungan Jakarta, Tesis Magister, Dep. Teknik Geologi ITB, tidak diterbitkan.

- Bear, J. 1979. Hydraulic of Groundwater. McGraw-Hill. New York.

- Direktorat Geologi Tata Lingkungan. Peta Hidrogeologi Indonesia. Lembar 1209-1. Bogor. Jawabarat. Disalin dari : Laporan Tahunan DGTL, 1994/1995.

- Fachri, M., Djuhaeni, Hutasoit, L.M., Ramdhan, A.M., 2002. Stratigrafi dan hidrostratigrafi Cekungan Airtanah Jakarta, Buletin Geologi Vol. 
34, No.3, 2002 (Special Issue), Departemen Teknik Geologi, Institut Teknologi Bandung (ITB).

- Freeze, Allan R., John A. Cherry. 1979. Groundwater. Prentice Hall. Englewood Cliffs, New Jersey.

- Hutasoit, L. M. 2004. Hidrogeologi Cekungan Jakarta untuk Pengembangan Resapan Buatan. Laboratorium Simulasi Numerik Hidrogeologi. Departemen Teknik Geologi. ITB.

- L. Huisman and T.N Olsthoorn, "Artificial Groundwater Recharge", Pitman Advanced Publishing Program, Boston - London Melbourne, 1983.

- RISTEK - ITB, "Laporan Penelitian Waduk Resapan", 2007/2008.

- $\quad$ RISTEK - ITB - BPPT, "Penyusunan Master Plan Situ Untuk Waduk Resapan di Jabodetabek", 2008.

- S. Legowo, Dr.Ir, "Application of Space Technology to Search The Recharging Reservoir Location for DKI Groundwater Recovery", LAPAN - Workshop, Jakarta 7 - 11 Juli 2008. 